\title{
METODE MENERJEMAHKAN KITAB KUNING DI PESANTREN MIFTAHULHUDA AL-MUSRI CIANJUR
}

\author{
Hasan Alwan \\ SMPN 1 Bojong Kabupaten Purwakarta \\ Pos-el: hasanalwan09@gmail.com
}

\begin{abstract}
Abstrak
Penelitian ini dilatarbelakangi oleh tradisi belajar di pesantren tradisional yang menjadikan kitab kuning sebagai referensi utama dalam pengajaran. Penelitian ini merupakan penelitian kualitatif deskriptif. Ada beberapa teknik pengumpulan data, di antaranya teknik observasi, wawancara, dan studi bibliografis. Dari penelitian ini ditemukan kaidah menerjemahkan kitab kuning berdasarkan ilmu nahwu dan shorof; empat metode yang digunakan dalam pengajaran yaitu sorogan, balagan, talaran, dan tarkiban; serta kemampuan santri yang tergolong kategori sedang. Penelitian tentang metode pengajaran menerjemahkan kitab kuning masih jarang diteliti. Oleh sebab itu, diperlukan penelitian lanjutan tentang sistem pengajaran di pesantren tradisional ditinjau dari beberapa aspek.
\end{abstract}

Kata Kunci: metode menerjemahkan, Kitab Kuning, pesantren tradisional

\section{THE TRANSLATION METHOD OF YELLOW (ISLAMIC CLASSICAL) BOOKS AT THE ISLAMIC SCHOOL OF MIFTAHULHUDAAL-MUNSRI CIANJUR}

\begin{abstract}
This study was conducted based on the learning tradition inpesantren that places kitab kuning as the main reference. This is a descriptive-qualitative study. The techniques used for collecting data are observation, interview, and library research. It was found that the translation of kitab kuning is based on nahwu and shor.There are four methods used, namelysorogan, balagan, talaran, and tarkiban. The translation skills of students could be categorized as medium. The study about the translating method of kitab kuning is still scarce. Therefore, further studies on different aspects of teaching and learning in traditional Islamic boarding schools are needed.
\end{abstract}

Keywords: translation method, Kitab Kuning, traditional Islamic boarding school

\section{PENDAHULUAN}

Pesantren merupakan jenis pendidikan Islam di Indonesia yang bersifat tradisional untuk mendalami agama Islam serta mengamalkannya sebagai pedoman hidup sehari-hari. Menurut Irfawaldi (2012) pesantren terbagi ke dalam dua jenis, yaitu pesantren salafiah dan halafiah. Pesantren salafiah merupakan jenis pesantren yang mengajarkan kitab-kitab klasik (kuning) tanpa mengajarkan pengetahuan umum. Ajaran-ajaran yang ada dalam kitab kuning merupakan pedoman hidup dan kehidupan yang sah dan relevan. Sah berartri ajarannya dipercaya bersumber dari kitab Allah (AlQur'an) dan sunah Rasulullah (Al-hadits), 
relevan berarti ajarannya masih tetap cocok dan bermanfaat sekarang maupun nanti. Oleh sebab itu pengajaran kitab klasik merupakan hal utama di pesantren untuk mencetak santri yang memiliki pengetahuan keislaman bahkan diharapkan bisa menjadi kyai. Menurut Muthohar (2007:26) secara metodik ada beberapa metode yang digunakan untuk menerjemahkan kitab kuning di pesantren di antaranya metode sorogan, bandongan/ balagan, dan halaqoh. Sorogan yaitu belajar secara individual dengan cara santri menghadap gurunya untuk mempelajari suatu materi pelajaran. Sehingga ada interaksi langsung dan saling mengenali antara santri dan gurunya. Bandongan yaitu model pengajian yang dilakukan seperti kuliah terbuka yang dihadiri oleh sekelompok santri berjumlah 100-500 orang atau lebih. Halaqoh yaitu model pengajian yang umumnya dilaksanakan dengan cara mengitari gurunya.

Pesantren halafiah atau modern merupakan pesantren yang menekankan pendidikan sistem formal dan bahasa Arab modern. Pesantren modern memiliki berbagai konotasi. Tidak ada difinisi dan criteria yang pasti untuk memenuhi atau pantas disebut pesantren modern. Namun, ada beberapa unsur yang menjadi ciri khas pesantren modern, di antaranya: 1) menekankan terhadap penggunaan bahasa Arab komunikasi, 2) menggunakan bukubuku literature bahasa Arab kontemporer, 3) memiliki sekolah formal yang menggunakan kurikulum Diknas atau Kemenag, dan 4) tidak menggunakan sistem pengajaran tradisional seperti sorogan dan balagan.

\section{METODE}

Metode yang digunakan dalam penelitian ini adalah kualitatif deskriptif dengan menggunakan studi kasus untuk menggambarkan secaraintensiflatarbelakang dan interaksi lingkungan yang berada di pesantren tradisional. Sukmadinata (2008: 77) menyebutkan studi kasus merupakan metode untuk mengumpulkan data berhubungan dengan suatu kasus. Kasus ini berhubungan dengan kaidah menerjemahkan kitab kuning, metode menerjemahkan kitab kuning, dan kemampuan santri dalam menerjemahkan kitab kuning.

\section{HASIL DAN PEMBAHASAN Kaidah Menerjemahkan Kitab Kuning Di Pesantren Miftahulhuda Al-musri Cianjur}

Kaidah menerjemahkan kitab kuning berkaitan dengan kaidah membaca bersumber pada tata bahasa Arab, yaitu satu sistem bahasa yang memiliki beberapa subsistem bahasa, di antaranya nahwu dan saraf. Nahwu dasar dan saraf dasar yang biasa digunakan untuk membantu memperlancar dalam membaca dan menerjemahkan kitab kuning yang bersumber pada kitab Jurumiyyah oleh Imam Abi Abdillah Muhammad Bin Daud Shanhiji, kitab At-tasrīfi Al-izzi oleh Izzudin Abi Al-fadhāil Ibrahim Bin Abdul Wahhab Bin Imaduddin Az-zinjani, kitab As-salsilu al-madkhal oleh Abu Hamid Muhammad bin Qadhi Muhammad Ilyas, buku Empat Langkah Membaca dan Menerjemah Kitab Gundul (Metode Assasakiy) oleh Abu Hilya Salsabila.

\section{Nahwu Dasar}

Dari hasil analisis data, tergambar dengan jelas bahwa nahwu diawali dengan membahas kalam. Pada struktur bahasa Arab, kalam sama dengan kalimah dalam bahasa Sunda. Sedangkan kalimah dalam bahasa Arab sama dengan kata dalam bahasa Sunda. Menurut Shanhaji (2008: 4) kalam yaitu lafadz yang tersusun dari dua huruf atau lebih yang memiliki arti yang sempurna dengan menggunakan bahasa Arab.

Dari hasil analisis data, terlihat jelas bahwa bahasa Arab memiliki empat harakat (baris) yang digunakan untuk merubah suara vokal huruf hijäiyyah. Harakat bahasa Arab di antaranya fathah (jabar) pada suara (a), kasrah (jéér) pada suara (i) dhammah 
(péés) pada suara (u), ada lagi yang menggunakan tanwin di antaranya: fathatain (tanwin jabar) pada suara (an), kasratain (tanwīn jéér) pada suara (in), dhammatain (tanwìn péés) pada suara (un). Selain dari harakat vokal, ada lagi yaitu sukun yang digunakan untuk mematikan suara akhir huruf hijaiyyah. Harakat yang berada diakhir kata dalam bahasa Arab sekaligus menjadi tanda kedudukan kata pada kalimah. Ilmu nahwu merupakan suatu pola membaca harakat (baris) akhir kata bahasa Arab untuk menentukan kedudukan pada pola kalimah. Salsabila (2012: 23-28) menyebutkan untuk memahami cara membaca harakat (baris ) akhir kata bahasa Arab, ada beberapa istilah yang harus dipahami untuk menguasai bahasa Arab yang berkaitan dengan kemampuan membaca dn menerjemahkan kitab kuning, di antaranya sebagai berikut:

1) Al-ismu al-mufrad, ialah kata benda tunggal. Ciri-ciri al-ismu, yaitu: a) diimbuhi huruf alif dan lām; b) tanwīn (apabila tidak ada alif-lām); dan c) kasrah (baris bawah).

2) Al-ismu al-mutsanna, ialah kata benda ganda yang diimbuhi alif-nūn atawa $y \bar{a}$ '-nūn diakhirnya.

3) Jam'u al-mudzakkar as-sālim, ialah kata benda jamak jenis laki-laki yang diimbuhi $w \bar{a} w u-n \bar{u} n$ atau $y \bar{a}{ }^{\prime}-n \bar{u} n$ diakhirnya.

4) Jam'u al-muannats as-sālim,ialah kata benda jamak jenis perempuan yang diimbuhi alif dan $t \bar{a}{ }^{`}$ diakhirnya.

5) Jam'u at-taksīr, ialah kata benda jamak meliputi jenis laki-laki dan perempuan.

6) Al-ismu al-ladzī lā yansharif, ialah semua isim selain yang sudah dijelaskan di atas. al-ismu al-ladzì lā yansharif terdiri atas:

a) semua ismu al-`alam (nama) yang diakhiri dengan tā' marbuthah (meskipun al-ismu al-mudzakkar);

b) semua ismu al-`alam al-muannats (meskipun tidak diakhiri $t \bar{a}$ marbuthah) yang lebih dari tiga huruf; c) ismu al-`alam yang merupakan kata serapan atau berasal dari bahasa ‘jam (non Arab);

d) ismu al-`alam yang menggunakan wazan fiil;

e) ismu al-`alam, yang menggunakan wazan fuialu (فُعَلُ) ;

f) semua al-asmā' (kata-kata benda), baik ismu al-`alam maupun bukan, yang diakhiri dengan huruf alif-nūn;

g) semua al-ismu yang menggunakan

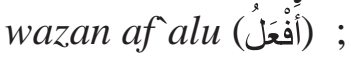

h) al-jam'u yang mempunyai wazan manun ditengahnya terdapat mad alif atau huruf setelahnya berjumlah dua huruf atau lebih.

i) al-`adad (عَدَ) atau bilangan dari satu sampai sepuluh yang menggunakan

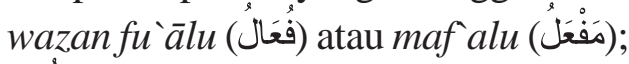

j) أَخرَّ (ukharu) bentuk jamak dari kata أُخْرَى ( $u k h r \bar{a})$; dan

k) kata benda yang huruf akhirnya alif mamdūdah atau alif lurus (اء).

7) Asmā ul-khamsah, ialah kata benda yang lima.

8) Fi'il mudhāri', ialah kata kerja yang menunjukan waktu sedang dan akan dating. Ciri-cirinya sebagai berikut: a) Diawali oleh salah satu dari huruf mudhāra'ah yang terangkum dalam kata أَنَيْن (anaitu); b) Dapat dimasuki huruf sin (س) انسوْنَ).

9) Al-af'ālu al-khamsah, ialah fi'il mudhāri' yang bertemu dengan alif tatsniyyah (alif yang menunjukan makna dua), wāwu jama' (wāwu yang menunjukan makna lalaki banyak), atau $y \bar{a}^{\prime}$ muannatsah mukhāthabah (yā' yang menunjukan kata ganti kedua untuk perempun). Bentuk alaf'àlu al-khamsah yaitu lima kata kerja.

Selain dari pada Sembilan istilah di atas ada beberapa istilah pendukung yang harus dipahami untuk menguasai basa Arab yang berkaitan dengan kemampuan membaca dan menerjemahkan kitab kuning, diantaranya sebagai berikut: 
1) Muannats, ialah kata benda yang menunjukan jenis perempuan. Biasanya ditandai dengan adanya $t \bar{a}{ }^{`}$ marbuthah pada kata benda tersebut.

2) Mudzakkar, ialah kata benda yang menunjukan jenis laki-laki. Biasanya ditandai dengan tidak adanya $t \bar{a}^{\prime}$ marbuthah pada kata benda tersebut.

3) Nakirah, ialah kata benda yang belum jelas peruntukannya. Secara mudah kita mengenalnya pada isim yang tidak diimbuhi alif dan lām.

4) Al-ma'rifah, ialah lawan dari nakirah. Adapun yang termasuk al-ma'rifah antara lain: a) ismu adh-dhamīr (kata ganti); b) ismu al-`alam (nama orang dan tempat); c) ismu al-isyārah (kata petunjuk); d) ismu al-maushūl (kata benda yang diimbuhi huruf alif dan lām); e) Al-idhāfah ialah dua kata benda yang digabung menmenjadi satu kata baru yang memiliki arti yang baru; dan f) al-munāda ialah kata yang biasa digunakan untuk menyeru seseorang.

Secara sederhana semua bagian dari alma`rifah di atas dapat disederhanakan menjadi:

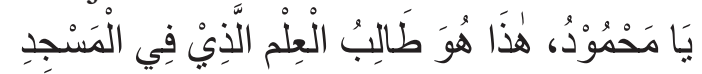

(Yā mahmūdu, hādzā huwa thālibu al'ilmi al-ladzi fi al-masjidi)

5) Al-mabnī, ialah kata benda yang tidak berubah-ubah keadaan syakal (harakat) akhirnya. Yang termasuk al-ismu almabnī adalah: adh-dhamīr, al-ismu alisyārah, al-ismu al-maushūl, ismu asysyarth, ismu al-istifhām dan sebagian zharaf.

6) Al-mu'rab, ialah kata benda yang berubah-ubah keadaan syakal (harakat) akhirnya.

7) Al-fi'lu al-mādhi, ialah kata kerja yang menunjukan waktu lampau. Ciri-cirinya: a) selalu fathah, sebelum bersambung dengan dhamir; b) dapat diawali huruf قَ (qad); dan c) kadang-kadang diakhiri

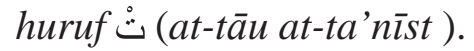

8) Fi'lu al-amr ialah kata kerja parintah. Ciri-cirinya huruf akhirnya selalu sukūn.

9) Al-fi'lu al-mabni, ialah kata kerja yang keadaan syakal akhirnya tetep (tidak berubah-ubah). Adapun yang termasuk al-filu al-mabni adalah: alfi'lu al-mādhi, al-fi'lu al-mudhāri' yang bersambung dengan $n n$ ün at-taukìd dan nūn an-niswah dan fi lu al-amr.

10) Al-fi'lu al-mu'rab, ialah kata kerja yang keadaan syakal akhirnya berubah-ubah. Adapun yang termasuk al-filu almu rab adalah: al-fi lu al-mudhāri yang tidak bersambung dengan nūn at-taukìd dan nün an-niswah.

11) Al-filu ash-shahīh ialah al-filu (kata kerja) yang huruf-hurufna tidak termasuk huruf 'illah (alif, wāwu dan $y \bar{a}$ ). Alfilu ash-shahīh terbagi tiga bagian; almahmūz, al-mudhāa af ats-tsulātsi dan as-sālim.

a) Al-mahmūz ialah al-filu ash-shahīh yang salah satu hurufnya terdapat huruf hamzah.

b) Al-mudhā'af ats-tsulātsi ialah al-fi'lu ash-shahih yang huruf 'ain fi il dan làm fi il dari jenis yang sama.

c) As-sālim ialah al-fil lu ash-shaīh yang salah satu hurufnya tidak dimasuki hamzah dan bukan tadh iff.

12) Al-fi lu al-mu`tall, adalah al-fi $l u$ (kata kerja) yang huruf-huruf aslinya salah satu huruf 'illah (alif, wāwu dan $y \bar{a}{ }^{`}$ ). Alfilu al-mu'tall terbagi atas tiga bagian:

a) Al-mitsāl ialah al-fi'lu al-mu 'tall yang terdapat huruf 'illah pada fā' fi ill-nya.

b) Al-ajwaf ialah al-filu al-mu'tall yang terdapat huruf 'illah pada `ain fiil-nya.

c) An-nāqish ialah al-filu al-mu'tall yang terdapat huruf 'illah pada lām fi il-nya.

13) Al-fi lu al-muta 'addi ialah kata kerja yang membutuhkan mafūl bih untuk menyempurnakan kalimah. Al-fi 'lu almuta `addi terbagi atas dua bagian di antaranya: 
a) Al-fi'lu al-muta`addi yang memiliki satu maf ùl bihi.

b) Al-fi 'lu al-muta addi yang memiliki dua maf ül bih atau lebih.

14) Al-fi'lu al-lāzim ialah kata kerja yang tidak membutuhkan al-maf ül bih dalam menyempurnakan makna kalimat.

15) Huruf, terbagi dua bagian di antaranya:

a. Huruf mabāni atau huruf hijā $i$ yaitu huruf yang dapat membentuk satu kata.

b. Huruf ma`āni yaitu huruf-huruf yang sudah memiliki arti tersendiri.

\section{Cara Membaca Al-majrūr}

Menurut Shanhaji (2008: 5) al-majrūr dapat disebabkan beberapa hal di antaranya: 1) huruf al-jarr atau al-qasam (sumpah);2) al-idhāfah; dan 3) at-tawābi` lil-majrūr

Tanda baca al-majrūr ada tiga di antaranya: 1) Al-kasrah menmenjadi tanda baca untuk al-ismu majrūr, pada al-ismu al-mufrad, jam `u at-taksir dan jam`u almuannats as-sālim, 2) Al-fathah menmenjadi tanda baca untuk al-ismu majrūr pada alismu al-ladzi lā yansharif; jeung 3) Huruf yā' menmenjadi tanda baca untuk al-ismu majrūr pada al-mutsanna, jam `u al-mudzakkar assālim dan al-asmā al-khamsah.

\section{Cara Maca `Al-Marfü}

Menurut Shanhaji (2008: 12) kedudukan al-marfū ada dalapan, di antaranya: 1) $\mathrm{Al}$ fāill; 2) Nāibu al-fāiil; 3) Al-mubtada'; 4) Khabar al-mubtada; 5) Ismu kāna; 6) Khabaru inna; 7) At-tawābi li al-marfū'; dan 8) Al-fi' 'lu al-mudhāri'“al-marfū'.

Menurut Shanhaji (2008, halaman 6) al-marfü memiliki empat tanda baca, yaitu: dhammah, wāwu, alif dan tsubūt an-nūn (tetapnya nūn).

1) Dhammah menjadi tanda untuk al-marfū' pada al-ismu al-mufrad, jam 'u at-taksīr, jam`u al-muannats as-sālim dan al-filu al-mudhāri al-marfū'.

2) Wāwu menjadi tanda untuk al-marfū' pada jam`u al-mudzakkar as-sālim dan al-asmāu al-khamsah.
3) Alif menjadi tanda untuk al-marfū pada al-mutsanna.

4) Tsubūt an-nūn (tetapnya nūn) menjadi tanda untuk al-marfū pada al-af'ālu alkhamsah.

\section{Cara Membaca Al-manshūb}

Menurut Salsabila (2012: 118) kedudukan al-manshūb ada tiga belas, di antaranya: al-maf ūl bihi, al-maf $\bar{u} l$ fìhi, almaf' ūl li ajlihi, al-maf'ūl muthlaq, al-maf'ūl ma`ah, al-hāl, at-tamyīz, al-mustatsnā, khabaru kāna, ismu inna, al-munāda, attawābi li al-manshūb, dan al-fi'lu almudhāri`al-manshūb.

Tanda baca al-manshūb ada lima, di antaranya sebagai berikut ini

1) Al-fathah pada; al-ismu al-mufrad, jam `u at-taksìr dan al-fi 'lu al-mudhāri

2) Al-alif pada; al-asmā al-khamsah

3) Al-kasrah pada; jam ‘u al-muannats assālim

4) Al-yā' pada; al-mutsanna dan jam`u almudzakkar as-sālim

5) Hadzfu an-nūn (menghilangkan nūn) pada; al-af āl al-khamsah.

\section{Cara Maca Al-majzūm}

Menurut Shanhaji (2008: 11) Al-filu al-mudhāri al-Majzūm ialah al-fi'lu almudhāri yang didahului huruf jazm.

Dari hasil analisis data, huruf jazm terbagi dua bagian, yaitu yang men-majzūmkan satu al-fi lu dan yang men-majzüm-kan dua al-filu.

Tanda baca majzūm aya tilu, di antaranya: 1) as-sukūn pada al-filu ash-shahīh; 2) menghilangkan huruf al-'illah pada al-fi 'lu al-mu'tal al-akhìr; dan 3) menghilangkan huruf an-nūn pada al-af āl al-khamsah.

\section{Ilmu Sharf Dasar}

Menurut Salsabila (2012: 227-229) ada beberapa istilah sharaf yang perlu diketahui agar dapat menguasai bahasa Arab berkaitan dengan kemampuan membaca dan menerjemahkan kitab kuning, di antaranya: 
1) Al-wazan ialah timbangan atau pola dasar kata kerja kecap pagawéan anu ku timbangan atawa pola dasar éta bakal ngagampangkeun pikeun nganyahokeun wangun-wangun kecap nu séjénna. Pola dasar pada basa Arab geus dirumuskeun pada pola: $f a$ - ` $a$ - la (فَ)

2) Al-mauzūn ialah kata yang ditimbang atau dipola.

3) Al-fi lu ats-tsulātsi ialah kata kerja yang huruf aslina tilu huruf.

4) Al-filu ats-tsulātsiy al-mujarrad ialah kata kerja yang huruf asalnya tiga huruf dan belum berimbuhan.

5) Al-fi'lu ats-tsulātsiy al-mazìd ialah kata kerja yang huruf asalnya tiga huruf dan sudah berimbuhan.

6) Al-filu ar-rubāi i ialah kata kerja yang huruf asalnya empat huruf.

7) Al-fi lu ar-rubāi $i$ al-mujarrad ialah kata kerja yang huruf asalnya empat huruf yang belum berimbuhan.

8) Al-fi lu ar-rubā $i$ al-mazìd ialah kata kerja yang huruf asalnya empat huruf dan sudah berimbuhan.

9) Shighat ialah bentuk kata dipandang dari segi makna.

10) Binā ialah bentuk kata dipandang dari segi hurufnya.

11) Tashrifishthilahiialah merubah satu bentuk asal menmenjadi beberapa perubahan.

12) Shighat ism al-mashdar ialah bentuk isim yang menunjukan makna pekerjaan.

13) Shighat ism al-fā il ialah bentuk isim yang menunjukan makna pelaku.

14) Shighat ism al-maf $\bar{u}$ ialah bentuk isim yang menunjukan makna objek (penderita).

15) Shighat fi il an-nahi ialah bentuk isim yang menunjukan makna larangan.

16) Shighat ism al-makan ialah bentuk isim yang menunjukan makna tempat pekerjaan itu dilaksanakan.

17) Shighat ism az-zamān ialah bentuk isim yang menujukan makna waktu pekerjaan itu dilakukan.
18) Shighat ism al-alat ialah bentuk isim yang menunjukan makna alat yang digunakan.

19) At-tashrīf al-lughawi ialah merubah satu bentuk asal menmenjadi beberapa parubahan sesuai dengan kata penggantinya.

20) Binā`al-fìil ash-shahīh ialah kata kerja yang huruf-hurufnya tidak termasuk huruf 'illah (alif,wāwu dan yā').

21) Binā 'al-mahmūz ialah al-fi 'lu ash-shahīh yang salah satu huruf asalnya hamzah.

22) Binā`al-mudha ‘af ats-tsulātsi ialah alfilu ash-shahīh yang huruf 'ain dan lam fi il-nya dari satu jenis.

23) Binā `as-sālim ialah al-fi'lu ash-shahīh yang salah satu hurufnya tidak termasuk huruf hamzah dan bukan tadh if.

24) Binā' al-fi ‘u al-mu`tall ialah kata kerja yang huruf asalnya merupakan salah satu huruf 'illah (huruf alif, wāwu dan $\left.y \bar{a}{ }^{\prime}\right)$.

25) Binā’ al-mitsāl ialah al-filu al-mu`tall yang huruf illah-nya terdapat pada huruf kesatu ( $f a^{\prime} f i$ il)

26) Binā’ al-ajwaf ialah al-fi'lu al-mu`tall yang huruf illah-nya terdapat pada huruf kedua ('ain fi il).

27) Binā`an-nāqish ialah al-fi 'lu al-mu`tall yang huruf illah-nya terdapat pada huruf ketiga (lām fi ill).

28) Binā’ al-lafif ialah al-fi'u al-mu`tall yang huruf 'illah-nya ada dua.

Ilmu ash-sharaf atau ilmu tashrïf memiliki arti ilmu untuk merubah. Sedangkan sacara istilah ialah ilmu untuk mengetahui perubahan kata dari satu kata dasar menjadi beberapa kata lain (Salsabila, 2012: 230).

Menurut Hamid (2008, kaca 3) ilmu sharaf dasar memiliki dua puluh dua bab awzān at-tashrif yang termasuk bab pokok (awzān mulhaq bih), tapi jika dihitung dengan awzān cabang (awzān mulhaqū) maka jumlahnya ada tiga puluh sembilan bab, terbagi atas empat bagian di antaranya:

1) Bagian kesatu: Ats-tsulātsi al-mujarrad ada 6 bab. 
2) Bagian kedua: Ats-tsulātsi al-mazìd ada 12 bab.

3) Bagian katiga: Ar-rubā $i$ al-mujarrad ada 1 bab (mulhaq bih), mimiliki cabang 6 bab (mulhaqī).

4) Bagian keempat: Ar-rubā $i$ al-mazìd ada 3 bab (mulhaq bih), memiliki cabang 11 bab (mulhaq $\bar{l}$ ) di antaranya:

a. Bab kesatu memiliki 8 bab (mulhaq $)$;

b. Bab kedua memiliki 2 bab (mulhaq $)$;

c. Bab ketiga memiliki 1 bab (mulhaqī).

\section{Metode Pengajaran Menerjemahkan Kitab Kuning}

Berdasarkan hasil observasi di Pesantren Miftahulhuda Almusri Cianjur, ada beberapa metode yang digunakan dalam pengajaran kitab kuning. Di bawah ini dibahas metode utama yang digunakan yaitu metode sorogan, balagan, tarkiban, dan hapalan.

\section{1) Metode Sorogan}

Metode sorogan merupakan metode pengajran menerjemahkan kitab kuning yang paling sulit dibandingkan dengan jenis-jenis metode menerjemahkan kitab kuning lainnya. metode ini dianggap sulit dikarenakan memerlukan keterampilan, kedisiplinan, kesabaran, serta ketaatan dari seorang santri. Santri secara eksklusif diarahkan, diawasi, serta dinilai oleh gurunya mengenai bacaan serta keterampilan menerjemahkan kitab kuning. Kyai, ustad, dan santri banyak yang memiliki pendapat bahwa metode ini efektif untuk menguasai keterampilan menerjemahkan kitab kuning. Disebut efektif, karena santri secara langsung membacakan teks terus menerjemahkan berdasarkan kaidah yang berlaku di depan gurunya. Peran ustad sangatlah besar dalam membimbing dan mengarahkan santrinya. Dalam metode sorogan ada beberapa tahapan yang harus ditempuh di antaranya di bawah ini.

\section{a) Perencanaan}

Tahap perencanaanmemberikesempatan terhadap santri untuk mempersiapkan materi yang akan diserahkan kepada ustadnya. Dalam pengajaran sorogan, biasanya santri memiliki dua kitab. Satu kitab digunakan menuliskan dahulu materi kitab yang akan diterjemahkan untuk diberi baris (harakat), diterjemahkan berdasarkan kemampuannya. Dalam memaknai teks yang belum dipahami, santri melihat kamus atau menanyakan kepada santri yang lebih paham sahingga santri merasa siap untuk membacakan materi kitab kuning yang akan diterjemahkan. Kitab yang kedua merupakan kitab kosong yang akan dibacakan dan diterjemahkan dihadapan ustadnya. Kitab yang kedua ini tidak boleh ditulisi baris dan terjemahan.

\section{b) Kegiatan Inti}

Metode sorogan memerlukan perencanaan yang sangat matang untuk mencapai keterampilan menerjemahkan dalam kegiatan inti. Selain keterampilan santri dalam menerjemahkan kitab kuning, mental santri dalam menghadapi ustad yang sangat dihormatinya perlu pembiasan yang sering dan kontinyu. Sebab banyak santri yang memiliki kemampuan menerjemahkan, tetapi tidak kuat mentalnya ketika berhadapan dengan ustadnya sehingga santri kehilangan konsentrasi dalam membacakan teks kitab kuning yang akan diterjemahkan. Kontribusi ustad untuk memberikan ketenangan untuk santri ketika proses pengajaran sangatlah penting. Hal ini diperlukan supaya santri tenang dan bisa memusatkan perhatiannya untuk menerjemahkan kitab kuning. Ada beberapa langkah yang ditempuh dalam kegiatan ini, di antaranya di bawah ini.

(1) Santri menyerahkan materi teks kitab kuning yang sudah disiapkan di hadapan ustadnya untuk dibacakan serta diterjemahkan berdasarkan kaidah yang berlaku.

(2) Ustad menyimak bacaan dan terjemahan teks kitab kuning santri. Selanjutnya ustad meluruskan bacaan dan terjemahan santri yang dianggap salah.

(3) Seandainya belum merasa paham, santri bisa langsung menanyakan masalah 
yang dianggap belum dipahami. Ustad menjawab pertanyaan santri untuk memberikan pemahaman masalah tersebut.

(4) Santri menuliskan terjemahan yang benar sesuai arahan ustadnya. Biasa proses ini ditulis secara singkat menggunakan symbol-simbol tertentu dikarenakan waktu yang sangat singkat.

(5) Setelah santri selesai membacakan teks kitab kuning yang diterjemahkan, ustad memberikan kesempatan kepada santri untuk menanyakan kembali materi kitab kuning yang belum dipahaminya.

(6) Untuk meyakinkan kemampuan pemahaman santri, ustad memberikan pertanyaan mengenai materi kitab kuning atau member tugas berkaitan dengan materi teks kitab kuning yang sedang dipelajari untuk lebih mendalami materi tersebut.

\section{c) Kegiatan setelah Pembelajaran}

Setelah selesai kegiatan sorogan, santri secara mandiri menuliskan kembali hasil terjemahan serta keterangan tambahan mengenai materi teks kitab kuning yang dipelajari. Hal ini dilaksanakan untuk lebih memahami dan membiasakan kedisiplinan menghapal materi yang ditemukan ketika proses sorogan.

Metode sorogan memiliki kelebihan dan kekurangan. Kelebihan metode sorogan di antaranya di bawah ini.

(1) Bersifat student centre sehingga santri dapat aktif dalam proses pembelajaran.

(2) Kemampuan santri dapat langsung terukur oleh ustadnya sebab langsung saling berhadapan.

(3) Mental santri dapat lebih terasah.

(4) Santri yang tekun bisa dengan cepat menyelesaikan suatu kitab yang dipelajarinya sehingga dapat meningkatkan kompetensi santri tersebut.

(5) Santri bisa langsung menyampaikan pertanyaan mengenai materi kitab kuning yang belum dipahaminya.
(6) Bisa membangun karakter santri yang cepat, tepat, dan benar dalam menerjemahkan kitab kuning.

Kelemahan metode sorogan di antaranya di bawah ini.

(1) Ustad pengajar yang berbeda akan berpengaruh terhadap kompetensi santri.

(2) Ada beberapa santri yang belum siap tapi dipaksakan untuk mengikuti metode ini. Santri yang belum siap ini dikarenakan pemahaman ilmu nahwu dan shorof yang lemah serta perbendaharaan kosa katanya masih minim.

(3) Mental santri yang kurang baik menyebabkan metode sorogan tidak akan berjalan lancar.

(4) Santri yang kurang tekun pasti akan sulit untuk menyelesaikan materi kitab yang diterjemahkan.

Untuk mengatasi kelemahan metode sorogan ini, peran ustad untuk membimbing serta memotivasi santrinya sangatlah penting serta pembiasaan santri untuk memiliki mental dan kedisiplinan yang baik dalam pengajaran untuk mencapai keterampilan menerjemahkan kitab kuning.

\section{2) Metode Balagan atau Bandongan}

Metode balagan merupakan metode pengajaran kitab kuning dengan cara ustad membacakan, menerjemahkan, dan menjelaskan materi teks kitab kuning. Santri bertugas menyimak dan menulis terjemah, syakal, dan keterangan tambahan yang diperlukan. Langkah-langkah pengajaran kitab kuning menggunakan metode balagan di antaranya di bawah ini.

(1) Ustad memusatkan perhatian santri untuk mengikuti pengajaran kitab kuning yang sudah ditentukan. Ustad membacakan, menerjemahkan, dan membahas materi kitab kuning yang diajarkan.

(2) Santri menulisakan logatan kitab kuningnya menggunakan Arab pegon dan symbol-simbol tertentu.

(3) Setelah selesai membacakan dan menerjemahkan, ustad memberikan 
kesempatan kepada santri untuk menanyakan kembali materi kitab kuning yang belum dipahaminya.

(4) Ustad menjawab dan membahas materi yang diajukan oleh santrinya.

(5) Ustad membuat kesimpulan mengenai materi teks kitab kuning yang diterjemahkan.

Metode balagan memiliki kelebihan dan kekurangan. Kelebihan metode balagan di antaranya di bawah ini.

(1) Seluruh santri bisa mengikuti proses pengajaran.

(2) Ustad mudah untuk menguasai kelas, sebab memiliki kekuasaan penuh untuk mengatur kelas.

(3) Santri menerima pemahaman secara langsung komfrehensif dari mulai membacakan, menerjemahkan, dan penjelasan langsung dari ustadnya.

(4) Waktu yang relatif panjang memberikan kesempatan santri untuk menulis catatan tambahan mengenai materi kitab kuning yang diterjemahkan.

(5) Materi kitab kuning yang diterjemahkan santri sama.

Kelemahan metode balagan di antaranya di bawah ini.

(1) Santri pasif dalam proses pengajaran, sebab tugasnya hanya menyimak bacaan terjemahan ustadnya.

(2) Ustad kurang memahami kemampuan santrinya.

(3) Tidak semuanya santri memiliki kesempatan untuk menanyakan materi kitab kuning yang belum dipahaminya.

(4) Seandainya terlalu lama dilkasanakan bisa menyebabkan santri bosan.

Untuk mengatasi kelemahan metode balagan, setiap seminggu sekali santri membahas materi kitab yang diterjemahkan di hadapan gurunya. Hal ini dilakukan untuk mengetahui kemampuan santri mengenai materi kitab kuning yang diajarkan.

\section{3) Metode Hapalan atau Tahfid}

Metode hapalan atau tahfid merupakan metode belajar kitab kuning dengan cara menghapal kitab kuning dengan bimbingan dan pengawasan ustadnya. Para santri diberikan tugas menghapal teks kitab kuning dalam jarak waktu yang sudah ditentukan. Proses pengajaran hapalan melalui cara santri diberikan tugas menghapal teks kitab kuning. Sesuai jadwal hapalan, santri menyetorkan hapalan kitab kuning kepada ustadnya. Metode hapalan memiliki kelebihan dan kelemahan. Kelebihan metode hapalan di antaranya di bawah ini.

(1) Pengetahuan santri tidak cepat hilang, karena materi kitab kuning telah dihapal.

(2) Tumbuhnya keinginan untuk membaca dan rajin belajar akibat dari target hapalan.

(3) Santri lebih percaya diri seandainya hapalannya lebih banyak dibandingkan dengan santri lainnya.

(4) Metode anu dianggap paling gampang ku santri.

(5) Cara mengatasi perasaan tidak menguasai materi pengajaran bisa dicoba dengan cara menghapal.

Kelemahan metode menghapal di antaranya di bawah ini.

(1) Pola pemikiran santri menjadi statis, akibat mengetahui apa yang dihapalnya saja.

(2) Tidak memiliki pendapat sendiri mengenai pemahaman suatu materi, sebab pendapat yang diajukan merupakan hasil hapalan.

(3) Menghapal materi yang berat dapat menyebabkan mental tidak tenang.

(4) Apabila materi kitab telah selesai, biasanya menghapal tidak diperdulikan lagi.

Untuk mengatasi kelemahan metode ini dengan cara ustad membahas dan menjelaskan materi yang dihapal sehingga santri memahaminya, motivasi dari ustad mengenai pentingnya menghapal, dan memberikan teknik menghapal secara cepat serta efektif. 


\section{4) Metode Tarkiban/Munadoroh}

Metode tarkiban yaitu metode gabungan dari metode diskusi dan debat. Biasanya dilaksanakan seminggu sakali. Metode ini memerlukan perencanaan, kerja sama, dan keberanian santri untuk menyampaikan pendapatnya. Langkah-langkah metode tarkiban di antaranya di bawah ini.

(1) Ustad membagi santri ke dalam beberapa kelompok, biasanya sekelompok santri berjumlah lima sampai dengan delapan orang.

(2) Tiap kelompok berdiskusi untuk menentukan pertanyaan yang akan disampaikan ke kelompok lain. Hal ini dilaksanakan untuk saling menguji tingkat kemampuan masing-masing kelompok.

(3) Ustad memberikan kesempatan untuk tiap kelompok bertanya ke kelompok lain secara adil.

(4) Kelompok yang penjawab, membahas jawabannya oleh juru bicaranya.

(5) Seandainya tidak sesuai dengan jawaban yang diharapkan, maka kelompok penanya bisa menolak jawaban tersebut.

(6) Selain dua kelompok itu, kelompok lain memilki kesempatan untuk menerima, menambahkan, bahkan untuk menolak pendapat kelompok lain.

(7) Setelah selesai, ustad dan santri membuat kesimpulan mengenai materi yang ditarkibkan.

Metode tarkiban memiliki kelebihan dan kekurangan. Kelebihan metode tarkiban di antaranya di bawah ini.

(1) Menyadarkan santri tentang banyaknya alternatif untuk menyelesaikan suatu masalah.

(2) Membiasakan berani untuk mengungkapkan gagasannya secara konstruktif sehingga menghasilkan keputusan yang lebih baik.

(3) Membiasakan santri untuk toleransi dalam menyimak pendapat santri lain yang berbeda dengan pendapatnya.
(4) Santri lebih aktif dan kritis.

(5) Keadaan kelas lebih hidup dan semangat. Kelemahan metode tarkiban antara lain di bawah ini.

(1) Tidak bisa digunakan untuk kelompok yang banyak anggotanya.

(2) Pesertanya hanya menguasai informasi yang kurang komfrehensif.

(3) Bisa didominasi oleh santri yang berani dan pintar bicara.

(4) Kadang menimbulkan perselisihan setelah pelaksaann pembelajaran disebabkan tidak menerima pendapatnya berbeda dengan kelompok lain.

(5) Menggunakan waktu yang lama.

Untuk mengatasai kelemahan tersebut, peran ustad selaku motor tarkiban sangat penting. Motor tarkiban harus memiliki sifat adil, sportif, netral, toleransi, dan sabar. Hal ini berkaitan dengan proses tarkiban yang harus senantiasa kondusif serta menghasilkan kesimpulan yang mewakili pendapat semua kelompok.

\section{Kemampuan Santri dalam Menerjemahkan Kitab Kuning}

Ada beberapa tes yang dilaksanakan untuk mengetahui kemampuan santri dalam menerjemahkan kitab kuning, di antaranya tes tulis, baca, hapalan, dan tarkiban. Tes ini disesuaikan dengan metode pengajaran yang digunakan. Dari hasil analisis data diperoleh gambaran tentang kemampuan santri dalam menerjemahkan kitab kuning, di antaranya di bawah ini.

1) Kemampuan santri tingkat Ibtida'iyyah tergolong kategori sedang dengan ratarata hitung (x) 72.

2) Kemampuan santri tingkat Tsanawiyyah tergolong kategori sedang dengan ratarata hitung (x) 76 .

3) Kemampuan santri tingkat Aliyah tergolong kategori sedang dengan ratarata hitung (x) 72 .

4) Kemampuan santri tingkat Ma`had Ali tergolong kategori sedang dengan ratarata hitung (x) 77. 


\section{SIMPULAN DAN SARAN}

Kaidah menerjemahkan kitab kuning di Pesantren Miftahulhuda Al-musri bersumber kepada ilmu nahwu dan shorof. Ilmu nahwu berhubungan dengan sintaksis dan ilmu shorof berhubungan dengan morfologi. Ilmu nahwu mempelajari pola membaca harakat (baris) akhir kata bahasa Arab untuk menentukan kedudukan pada pola kalimah. Ilmu shorof mempelajari perubahan kata dari satu kata dasar menjadi beberapa kata lain.

Metode menerjemahkan kitab kuning di Pesantren Miftahulhuda Al-musri ada empat yaitu metode sorogan, balagan, hapalan, dan tarkiban.

Kemampuan santri di Pesantren Miftahulhuda Al-musri dalam menerjemahkan kitab kuning tergolong ke dalam kategori sedang.

Penelitian tentang metode pengajaran kitab kuning di pesantren tradisional masih jarang ditemukan. Metode tradisional masih sering dipertahankan, walaupun dianggap statis dan tradisional. Hal ini tentunya menjadi objek penelitia yang menarik. Oleh sebab itu, diperlukan penelitian lanjutan tentang sistem pengajaran di pesantren tradisional ditinjau dari beberapa aspek.

\section{PUSTAKA RUJUKAN}

Shanhaji, D. (2008). Matan Aj-jurumiyyah. Surabaya: CV. Al-Haramain Jaya.

Hamid, A. (2008). As-salsilu Al-madkhal Fī 'Ilmi At-tashrîf. Semarang: CV. Thaha Putra.

Irfawaldi (2012) Pesantren Salafiyah dan Pesantren Modern. [online]. Tersediadi:http:/www.makalah pendidikanirfawaldi.blogspot.com/ 2012/04/pesantren-salafiyah-danpesantren-modern.html. [Diakses 2 Desember 2013]

Muthohar, A. (2007). Ideologi Pendidikan Pesantren, Pesantren di Tengah Arus Ideologi-ideologi Pendidikan. Semarang: Pustaka Rizki Putra.

Salsabila, A.H. (2012). Empat Langkah Membaca dan Menerjemahkan Kitab Gundul (Metode Assasakiy). Bekasi: Ukhwatuna.

Sukmadinata, N. S. (2008). Metode Peneletian Pendidikan. Bandung: PT. Remaja Rosdakarya

\section{UCAPAN TERIMA KASIH}

Terima kasih dan penghargaan yang setinggi-tingginya sepantasnya penulis sampaikan kepada penyunting Jurnal Lokabasa yang telah memuat tulisan saya ini. 